\title{
Paulina Zgliniecka
}

Akademia Muzyczna w Krakowie

\section{"Życiopisanie" w operach Aleksandra Nowaka - Sudden Rain, Space Opera}

\section{Abstract}

“Life-writing" in Aleksander Nowak's operas: Sudden Rain and Space Opera

"Life-writing", manifesting itself in the extremely personal character of the composition, is one of the most important features of Aleksander Nowak's work, which clearly distinguish him from other composers. "Life-writing" conceals such creative inspirations as the methods and means of composing. Nowak very often draws topics or sound material of the composition from his own life experiences.

At the same time, he hopes to achieve a certain type of energy or emotions, which will then to evoke the feelings that are similar to those accompanying the writing of the piece. The issue of conveying in the work any or more specific, though significant, emotions is therefore a first-rate issue. For this reason, in his works the musical tradition is often combined with the popular and well-known music.

A specific representation of the idea of "life-writing" are Nowak's operas: Sudden Rain for soprano, baritone, mixed choir and chamber orchestra and two-act Space Opera for soprano, mezzo-soprano, countertenor, baritone, bass, mixed choir and symphonic orchestra.

\section{Keywords}

"life-writing", opera, Aleksander Nowak, "Space Opera", "Sudden Rain", relation between text and music 
Aleksander Nowak (ur. 1979) jest uznawany za jednego z najciekawszych, a przy tym najzdolniejszych przedstawicieli średniego pokolenia. W jego twórczości można wskazać kilka elementów pozwalających na utożsamianie jej z szeroko rozumianym postmodernizmem, takich jak: dyskurs z muzyką popularną, sięganie do różnych stylów, technik oraz estetyk i tym samym pojmowanie współczesnej muzyki jako swoistej "gry kontekstów" ${ }^{1}$, wreszcie zainteresowanie relacjami międzyludzkimi. Cechą wysoce indywidualną u Nowaka, stawiającą go w kręgu kompozytorów zaangażowanych, jest „życiopisanie”, które przejawia się w wyjątkowo osobistym charakterze kompozycji. Sam termin po raz pierwszy został użyty przez krytyka literackiego Henryka Berezę w kontekście twórczości Edwarda Stachury dla podkreślenia ścisłego związku między jego życiem i dorobkiem artystycznym. Mówił: „Życie Stachury było życiopisaniem, pisał całym sobą" ${ }^{2}$. W odniesieniu do dzieł Nowaka posłużył się nim wybitny krytyk muzyczny Andrzej Chłopecki, pisząc: „Charakterystyczną cechą i znakiem szczególnym przynajmniej kilku znaczących utworów Aleksandra Nowaka jest swoiste «życiopisanie»"3. Warto zatem przyjrzeć się związkom rzeczywistości prawdziwej i kreowanej w operach śląskiego kompozytora.

Muzyczną edukację Nowak rozpoczął od nauki gry na gitarze oraz fortepianie u państwa Grażyny i Grzegorza Dzierzgowskich, którą kontynuował w klasie gitary Bogusława Pietrzaka w Państwowej Szkole Muzycznej I i II stopnia w rodzinnym mieście ${ }^{4}$. Jednocześnie zaczął stawiać swoje pierwsze kompozytorskie kroki pod okiem ukraińskiej kompozytorki Uliany Bilan ${ }^{5}$. Naukę akademicką podjął w katowickiej Akademii Muzycznej im. Karola Szymanowskiego w 2001 roku w klasie kompozycji Aleksandra Lasonia - wysoce cenionego w polskim środowisku muzycznym twórcy i pedagoga, zaliczanego - obok Eugeniusza Knapika i Andrzeja Krzanowskiego - do tzw. „pokolenia

1 M. Trzęsiok, Muzyka rzeczywistego świata. Rozmowa z Aleksandrem Nowakiem, „Kwarta. Magazyn o polskiej muzyce współczesnej” 2011, nr 1 (16), https://pwm. com.pl/pliki/2/6/4/2637_2158_Kwartanr1sierpien2011.pdf [dostęp: 10.12.2016].

2 M. Buchnowski, Buty Ikara. Biografia Edwarda Stachury, fragment książki, http:// www.polskatimes.pl/kultura/ksiazki/a/stachura-stworzyl--zyciopisanie-jegopisarstwo-bylo-tozsame-z-jego-zyciem,12510960/ [dostęp: 31/o3/2018].

3 A. Chłopecki, MUZYKA 2.1: Aleksander Nowak, http://www.dwutygodnik.com/ artykul/1116-muzyka-21-aleksander-nowak.html [dostęp: 12.12.2016].

4 Strona internetowa kompozytora, http://www.aleknowak.com [dostęp: 10.12.2016].

5 Tamże. 
stalowowolskiego", kojarzonego szerzej z festiwalem Młodzi Muzycy Młodemu Miastu (lata 70. XX wieku) i kultywowaną wówczas ideą nowego romantyzmu. Studia magisterskie Nowak ukończył z wyróżnieniem w 2006 roku kompozycją Wyspa wichrów i mgieł na chór i orkiestrę symfoniczną. W tym samym roku, jako laureat stypendium Moritz von Bomhard Fellowship ${ }^{6}$, wyjechał na dwuletnie studia kompozytorskie do Stanów Zjednoczonych na Uniwersytecie w Louisville pod kierunkiem Steve’a Rouse'a.7 Tuż po powrocie do kraju (2008) rozpoczął pracę na macierzystej uczelni prowadząc zajęcia ze studentami (m.in. z instrumentacji i kompozycji, a także współczesnych technik kompozytorskich, podstaw kompozycji oraz partytury współczesnej) ${ }^{8}$. W 2010 roku otrzymał stopień doktora sztuki, w 2016 - habilitację. Od 2011 roku pełni także funkcję prezesa katowickiego oddziału Związku Kompozytorów Polskich ${ }^{9}$.

Nowak szybko wypracował sobie mocną pozycję w środowisku muzycznym. Jego artystyczne poczynania nie umknęły uwadze krytyków muzycznych, w tym przywoływanego już Andrzeja Chłopeckiego, który swoją opinię o młodym kompozytorze ujął w sposób następujący:

Aleksander Nowak ma już za sobą spektakularne zaistnienie w pejzażu nowej,
młodej polskiej twórczości kompozytorskiej, obfitującej w wyraziste i coraz
bardziej krystalizujące się w swych estetycznych wyborach i artystycznych
dokonaniach postacie jego pokolenia. Pokolenia - ujmijmy to umownie i me-
taforycznie - „po Pawle Mykietynie” (rocznik 1971). Debiut Nowaka wpisał
się w czas szczególnej aktywności kompozytorskiej jego rówieśników, w czas
ewidentnie następującej i obserwowanej przez krytykę muzyczną erupcji

6 „To unikatowe stypendium oferujące absolwentom kompozycji możliwość zdobycia tytułu magistra sztuki w dziedzinie kompozycji, koncentrując się na kompozycji na głos ze szczególnym naciskiem na dramatyczną kompozycję wokalną. Kompozytorzy wybrani do udziału w tym programie powinni pokazać zarówno skłonności, ale i umiejętności do pisania na głos ludzki. Stypendium patronuje Moritz von Bomhard - utalentowany kompozytor, dyrygent, pianista i producent operowy, odpowiedzialny w zasadzie w całości za „stworzenie” Kentucky Opera”, http:// louisville.edu/music/academics/areas-of-study/music-composition/moritz-von-bomhard-fellowships-in-music-composition [dostęp: 26.04.2017], tłum. własne.

7 Strona internetowa kompozytora, http://www.aleknowak.com [dostęp: 10.12.2016].

8 A. Nowok, Wizytówka Aleksandra Nowaka, http://meakultura.pl/publikacje/ wizytowka-aleksandra-nowaka-771 [dostęp: 12.12.2016].

9 [b.a.] Nowak Aleksander, http://festiwalprawykonan.pl/kompozytorzy-nowak-aleksander.php [dostęp: 15.06.2018]. 
młodych talentów twórczych. Z jednej strony sytuacja ta wydaje się korzystna, tworząca okres intensywny, czas swoistego fermentu, czas manifestowania się tego, co w polskiej twórczości nowe i skierowane ku przyszłości, z drugiej strony przecież jest to czas, gdy rozpoznanie pojedynczego talentu i wydobycie go $\mathrm{z}$ gęstego pejzażu pokoleniowego może sprawiać kłopot recepcji ${ }^{10}$.

Swoistym debiutem kompozytora była Sonata June-December na skrzypce i fortepian z 2005 roku, jednak to skomponowany rok później Fiddler's Green and White Savannas Never More na głosy męskie i orkiestrę kameralną przyniósł Nowakowi szerszy rozgłos (także poza granicami kraju: prawykonanie odbyło się podczas festiwalu "Aksamitna Kurtyna 2", 11 października 2006 roku we Lwowie, a rok później utwór reprezentował Polskę podczas 54. Międzynarodowej Trybuny Kompozytorów UNESCO w Paryżu ${ }^{11}$ ). Fiddler's Green and White Savannas Never More stanowiło pierwsze tak ważne zamówienie kompozytorskie, które śląski kompozytor otrzymał od Fundacji Przyjaciół „Warszawska Jesień” w ramach projektu stypendialnego Förderpreise für Polen, finansowanego przez monachijską Ernst-vonSiemens Musikstiftung. Był wówczas studentem ostatniego roku kompozycji na katowickiej Akademii Muzycznej ${ }^{12}$. Pierwsza część stypendium miała pomóc w sfinansowaniu morskiej żeglugi na Spitsbergen w 2005 roku. Jak się bowiem okazuje kolejną - obok muzyki - pasję kompozytora stanowi żeglarstwo: brał udział w kilku wyprawach dalekomorskich (oprócz wspomnianej, rok później był członkiem podróży organizowanej przez North-West Passage na szlaku: Polska - Islandia, którą udokumentowano w postaci wielokrotnie nagradzanego filmu W poszukiwaniu legendy z 2007 roku autorstwa Konstantego Kuklika, do której muzykę skomponował Aleksander Nowak ${ }^{13}$ ). Druga część wspomnianego stypendium miała zaś pomóc w nadaniu ostatecznego kształtu temu wyjątkowemu „dźwiękowemu dziennikowi podróży”, jak określił kompozycję Chłopecki ${ }^{14}$.

10 A. Chłopecki, dz. cyt.

11 Fiddlers Green and White Savannas Never More, http://ninateka.pl/audio/ aleksander-nowak-fiddlers-green-and-white-savannas-never-more-aksamitnakurtyna-2 [dostęp: 19.03.2018].

12 Tamże.

13 Tamże.

14 A. Chłopecki, dz. cyt. 
Nowak komponuje głównie muzykę instrumentalną i wokalno-instrumentalną. Istotne miejsce w jego twórczości zajmuje teatr operowy - oprócz trzech oper: Sudden Rain (2008), Space Opera (2014) oraz ahat ilī-Siostra bogów (2018) jest autorem multimedialnej instalacji - quasi-dramatu muzycznego Spoon River Anthology na głosy solowe i wideo do tekstów amerykańskiego poety Edgara Lee Mastersa z tomu Antologia Spoon River, stworzone we współpracy z Adamem Dudkiem podczas edycji Festiwalu „Warszawska Jesień” w 2012 roku ${ }^{15}$.

Twórczość śląskiego kompozytora utrwalona została na kilku albumach płytowych: dwóch monograficznych - Fiddler's Green (wydany w 2009 roku przez Śląskie Towarzystwo Muzyczne i Polskie Radio) oraz $3 \times 4+8$ (wydany w 2012 roku przez CD Accord), a także w ramach Kroniki Dźwiękowej Warszawskiej Jesieni (lata 2008, 2009, 2011) ${ }^{16}$.

\section{"Życiopisanie"}

Termin „życiopisanie” kryje w sobie zarówno twórcze inspiracje, jak i metody oraz środki kompozytorskie. U Nowaka przejawia się wyjątkowo osobistym charakterem kompozycji. Artysta niezwykle często czerpie temat bądź materiał muzyczny z własnych doświadczeń życiowych („Dostrzegam i doceniam znaczenie zwrotu autobiograficznego"17), a niekiedy sięga do autorskich utworów (dla przykładu fragment kompozycji, który powstał w okresie liceum stał się materiałem formotwórczym dla Sonaty „June-December" na skrzypce i fortepian z 2005 roku). Częściej jednak odwołuje się do cytatów „, zewnątrz”, co w jednej z rozmów z Marcinem Trzęsiokiem, argumentuje emocjami odczuwanymi podczas tworzenia:

Pisząc utwór, znajduję się w kręgu emocji, z którymi się te cytaty wiążą. Pochodzą z piosenek, utworów czy stylów, które w pewnym momencie życia były dla mnie istotne. A kiedy odwołuję się do wspomnień, proces pisania staje się intensywniejszy. Mam nadzieję, że skoro tak jest na etapie tworzenia,

15 Strona internetowa kompozytora, http://www.aleknowak.com.pl [dostęp: 10.12.2016].

16 Tamże.

17 J. Topolski, Nowe otwarcie: jesteśmy kosmitami, rozmowa z Aleksandrem Nowakiem, http://www.dwutygodnik.com/artykul/5917-nowe-otwarcie-jestesmy-kosmitami. html [dostęp: 23.02.2018]. 
to również na etapie odbioru w jakiś sposób znajdzie to swe odbicie, mimo że słuchacz nie ma klucza identyfikującego wszystkie cytaty ${ }^{18}$.

Z tego wynika, że przekazanie w dziele mniej lub bardziej konkretnych, lecz istotnych emocji, jest dla Nowaka najważniejszą kwestią. Naturalne i nieuniknione są więc wątki autobiograficzne w jego twórczości. Warto w tym miejscu przytoczyć utwór Last Days of Wanda B. na orkiestrę smyczkową z 2006 roku dedykowany zmarłej babci, w którym można odnaleźć ślady pieśni religijnych, popularnych przebojów, takich jak Ciagle pada zespołu Czerwone Gitary, oraz ludowych przyśpiewek, na przykład Głęboka studzienka. W komentarzu do kompozycji artysta wyjaśnił:

Utwór ten jest przede wszystkim dźwiękową impresją, ale też zapisem emocji towarzyszących pożegnaniu oraz zestawem migawkowych wspomnień, przeplatanych szczątkowymi cytatami ulubionych melodii Wandy B., której jest dedykowany ${ }^{19}$.

Komentarze - niejednokrotnie metaforyczne, aluzyjne i niejednoznaczne, szukające zagubionej gdzieś niezwykłości w zwyczajnym życiu - to kolejny dowód na to, jak silnie „życiopisanie” jest obecne w poetyce Nowaka. Ich nieco zaskakującą i nieoczywistą zarazem rolę kompozytor podsumował: „Staram się powiedzieć raczej za mało, choćby w gruncie rzeczy nic, niż za dużo" ${ }^{20}$. Natomiast teoretyk muzyki Agnieszka Nowok niezwykle celnie spostrzegła, że: „Krótkie notki ukazują świat widziany oczyma wnikliwego obserwatora rzeczywistości"21. I tak, dla przykładu, utwór Ciemnowłosa dziewczyna w czarnym sportowym samochodzie na orkiestrę kameralną z 2009 roku, napisany na zamówienie festiwalu „Warszawska Jesień”, został opatrzony słownym komentarzem, w którym kompozytor opisał, jak podczas postoju na czerwonym świetle spostrzegł w sąsiednim samochodzie tytułową ciemnowłosą dziewczynę, kiwająca głową w rytm piosenki słyszanej w radiu

18 M. Trzęsiok, Muzyka rzeczywistego świata. Rozmowa z Aleksandrem Nowakiem, „Kwarta. Magazyn o polskiej muzyce współczesnej” 2011, nr 1 (16), s. 2, https://pwm. com.pl/pliki/2/6/4/2637_2158_Kwartanr1sierpien2011.pdf [dostęp: 10.12.2016].

19 A. Nowak, The Last Days of Wanda B., http://www.aleknowak.com/pl/muzyka/ orkiestrowe/ [dostęp: 23.02.2018].

20 A. Nowok, Aleksander Nowak, http://musicfrompoland.eu/artykul/aleksander-nowak-7 [dostęp: 08.08.2017].

21 Tamże. 
(warto wspomnieć, iż w finałowej kulminacji utworu instrumenty dęte wykonują motyw z piosenki popularnej wokalistki pop - Rihanny).

Nieco humorystyczna wypowiedź kompozytora, dotykająca niejako kwestii „życiopisania”, wyraźnie wskazuje, iż szczególne mocno wpisują się w nią jego dwie pierwsze opery: jednoaktowe Sudden Rain z 2008 roku oraz Space Opera z 2014:

\footnotetext{
Agnieszka Nowok napisała ostatnio na „MEAKULTURZE”, że jednym z głównych tematów mojego „życiopisania” jest kryzys komunikacji międzyludzkiej, powołując się na Sudden Rain (operę o braku porozumienia) czy Widok z górnego piętra (notkę o samotności). Podobne komentarze pojawiły się po premierze Space Opera, w której faktycznie jednym z pierwszoplanowych wątków jest małżeński kryzys. Zrobiło mi się wówczas nieswojo, co powie na to moja żona, z którą świetnie się rozumiemy... Mogę powiedzieć, że mimo bardzo udanego pożycia małżeńskiego fascynuje mnie kwestia samotności w świecie, potencjalnego połączenia każdego z każdym, do którego w końcu nie dochodzi. A może właśnie dlatego mogę potencjalnego „bezkarnie" eksplorować te rejony...22
}

\section{Opery Aleksandra Nowaka}

Napisanie przez Nowaka opery wydaje się być naturalnym następstwem kompozytorskich poczynań do 2008 roku, kiedy to spod jego ręki wyszła jednoaktowa opera Sudden Rain. Warto wspomnieć, że autor znalazł się w gronie laureatów nagrody TVP Kultura Gwarancje Kultury 2011 (kategoria: muzyka poważna) dzięki skomponowaniu koncertu fortepianowego oraz wspomnianego Sudden Rain, w których to dziełach - jak określiła Kapituła Konkursu - „wykazał się odwagą w łączeniu znanych idiomów stylistycznych ze świeżością kompozytorskiego spojrzenia"23. Pierwszą oficjalną próbą zmierzenia się z głosem ludzkim był jego utwór dyplomowy, wieńczący naukę w katowickiej Akademii Muzycznej - Wyspa wichrów i mgieł na chór mieszany i orkiestrę symfoniczną z 2005 roku. W tym samym czasie skomponował przywoływane już wcześniej Fiddler's Green and White Savannas Never

22 J. Topolski, dz. cyt.

23 Gwarancje Kultury - Telewizja Polska, http://www.tvp.pl/kultura/wydarzenia/ gwarancje-kultury/laureaci-2011 [dostęp: 11.12.2017]. 
More (notabene utwór jest idealnym przykładem „życiopisania”, gdyż, jak określił Chłopecki, stanowi muzyczny dziennik podróży na Arktykę, do którego kompozytor-żeglarz „sięga po właściwy w tych okolicznościach «życiopisania» repertuar szantów autorstwa niejakiego Johna Connolly, siwobrodego barda morskich songów"24.)

W 2007 powstały dwa cykle pieśni: Songs of Caress na mezzosopran, skrzypce, wiolonczelę i fortepian do tekstów XIX- i XX-wiecznych poetów polskich oraz amerykańskich, a także Trzy krótkie pieśni na tenor i fortepian do utworów polskich liryków XX wieku. Dodatkowym impulsem do podjęcia wyzwań kompozytorskich, jakie stawia głos, wydają się być także dwuletnie studia na Uniwersytecie w Louisville, które jako stypendysta Moritz von Bomhard Fellowship Nowak odbył tuż po ukończeniu Akademii Muzycznej im. Karola Szymanowskiego w Katowicach. Stypendium to oferuje młodym kompozytorom możliwość zdobycia tytułu magistra sztuki w dziedzinie kompozycji.

\section{Sudden Rain}

Sudden Rain - operowy debiut młodego kompozytora - ujrzał światło dzienne w 2010 roku, dwa lata po ukończeniu, podczas jednego ze swoistych spotkań z muzyką współczesną, organizowanych przez Teatr Wielki - Operę Narodową w Warszawie. ${ }^{25}$ Pomysłodawcy cyklu Terytoria za główny cel obrali sobie:

\section{[...] pomoc w próbie odnalezienia i nakreślenia nowego oblicza opery. Ga- tunku, który zmienia dziś swoją definicję, podbijając nowe terytoria, kreśląc odmienne sensy, proponując nową estetykę ${ }^{26}$.}

Głównym zagadnieniem, wokół którego kompozytor zbudował treść Sudden Rain, jest nieporozumienie albo też brak porozumienia między dwojgiem najbliższych sobie osób - mężem i żoną. O tym, że opera będzie poruszać kwestie relacji międzyludzkich, Nowak wiedział od samego początku, co wyznał w jednej z rozmów z Marcinem

24 A. Chłopecki, dz. cyt.

25 Tamże.

26 Terytoria, http://teatrwielki.pl/activity/artistic-projects/territories/ [dostęp: 07.08.2017]. Podczas tego samego koncertu oprócz wspomnianej kompozycji wykonano także operę Between Agaty Zubel. 
Trzęsiokiem ${ }^{27}$. Kwestią problematyczną okazał się jednak dobór libretta. Na przekór obecnej w operze nieco „sztucznej” konstrukcji języka szukał tekstu, który przypominałby mowę potoczną ${ }^{28}$. Pracę nad librettem poprzedził zatem długi rekonesans w kręgu sztuk teatralnych. Wynikłe z tego złe doświadczenia zmusiły kompozytora do podjęcia próby napisania libretta samodzielnie. Ostatecznie do współpracy zaprosił Annę Konieczną ${ }^{29}$. Wspólnie stworzyli dialog pary małżeńskiej (Ona i On), w który wpletli abstrahujące od głównej treści opery wypowiedzi chóru, wykorzystujące zapiski osoby cierpiącej na zespół Aspergera:

\footnotetext{
Stworzyliśmy dość krótkie libretto - dialog pary małżeńskiej, która się nie rozumie. Do tego dodałem swoisty kontrapunkt, trochę wzorem opery Philipa Glassa Einstein on the Beach, napisanej częściowo do tekstów poety autystycznego Christophera Knowlesa. [...] idąc za tym tropem, na nieco innej zasadzie wykorzystałem w libretcie zapiski osoby autystycznej ${ }^{30}$.
}

Zgodnie z pomysłem Nowaka na tekst Sudden Rain składają się dialog pary małżeńskiej, podsumowującej swój związek w dniu rocznicy ślubu oraz „kontrapunktujące” (określenie kompozytora) zapiski osoby z zespołem Aspergera (wzorem pomysłu z opery Glassa). W rzeczywistości libretto nie przekazuje zbyt wielu informacji ani o głównych bohaterach, ani o sytuacji, w jakiej rozgrywa się akcja utworu. Ona i On są z pozoru wzorcowym małżeństwem, czego potwierdzenie stanowi wypowiedź chóru z pierwszej sceny opery:

Dzisiaj jest ich rocznica ślubu.

Poślubieni w gorący letni dzień

wciąż razem po długich nocach zimy

hodują bazylię na parapecie

kupują chleb i mleko do kawy,

odmierzają czułość, kłótnie, złość, niecierpliwość, pocałunki.

Dzisiaj jest ich rocznica ślubu ${ }^{31}$.

27 M. Trzęsiok, dz. cyt., s. 4.

28 Tamże.

29 Anglistka, prawnik i socjolog. Prywatnie siostra żony Nowaka.

30 M. Trzęsiok, dz. cyt., s. 4.

31 A. Nowak, A Konieczna, Sudden Rain - libretto (materiały udostępnione autorce przez kompozytora). 
Cała historia rozgrywa się w parku i na dworcu w dniu kolejnej rocznicy ślubu głównych bohaterów. Małżonkowie, prowadząc rozmowę o pogodzie, w rzeczywistości odkrywają prawdę o swoim małżeństwie; o niezauważonym problemie i konflikcie, jaki między nimi narastał, czego zwiastunem jest nadchodzący, tytułowy nagły deszcz. Zdaniem Magdaleny Stochniol ta banalna na pierwszy rzut oka fabuła staje się:

[...] przyczynkiem do zadania ważnych pytań: o relacje człowieka z drugim człowiekiem, o samotność w związku, w końcu - o kondycję instytucji małżeństwa, niegdyś uświęconą, dziś nietrwałą i dla wielu bez większego znaczenia ${ }^{32}$.

Oprócz wzmianki o rocznicy, libretto przekazuje także informacje o przygotowanym przez niego prezencie dla ukochanej z okazji ich święta. Ma być nim coś, co wydaje mu się dla żony najważniejsze wolność, którą materializuje w postaci biletu lotniczego w jedną stronę. Ona odczytuje gest opatrznie - nie jako symbol miłości, a wyraz odrzucenia. Zaistniałą sytuację komentuje chór złożony z przypadkowych ludzi zebranych w parku. W swojej funkcji nawiązuje zatem do chórów z greckich tragedii - komentujących, a przy tym bacznie obserwujących rozwój akcji i poczynania bohaterów. W libretcie wyróżnić można cztery sceny, w ramach których wyraźnie wyczuwalna jest klasyczna struktura dramatu z podziałem na ekspozycję, rozwinięcie, kulminację i tragiczne rozwiązanie akcji. Treść opery niesie więc ze sobą uniwersalne przesłanie dotyczące kryzysu związku dwojga ludzi, wzmacniane nagłym zakończeniem akcji oraz anonimowością wynikającą z faktu, że główni bohaterowie nie posiadają imion (Ona, On). Prowokuje do pogłębionej, indywidualnej refleksji, w związku z czym można dowolnie interpretować miejsce wydarzeń, czas itd. Najważniejsze nie jest to, co było "przed” i wydarzy się „po". Istotne jest to, co „tu i teraz” - ta krótka chwila, rozmowa małżonków. $Z$ drugiej strony problem jest bardziej złożony, ukazany z perspektywy przyczyn i konsekwencji działań bohaterów. Libretto trafnie określa Stochniol, porównując je do lustra, które: „[...] kompozytor postawił przed słuchaczami, pozwalając przejrzeć się im i być może zobaczyć obrazy z własnego życia” ${ }^{33}$.

32 M. Stochniol, "Sudden Rain" (20o8) Aleksandra Nowaka. Niezwyczajna opera o zwyczajnych problemach, „Res Facta Nova” 2013, nr 14 (23), s. 140.

33 Tamże, s. 144. 
By przełamać „banalność” rozmowy głównych postaci, do tekstu głównego wprowadzono wątki poboczne. Pierwszym jest wspomniany już „kontrapunkt”, który stanowią teksty osoby autystycznej, potęgujące efekt niezrozumienia między małżonkami. Można odczytać je jako symbol „[...] zdezorientowania, zagubienia się w świecie ludzkich relacji, pełnym interpretacyjnych, bolesnych przeinaczeń" ${ }^{34}$. To zupełnie nowa jakość, którą Magdalena Stochniol odczytuje jako chwyt otwierający interpretację kompozycji:

\begin{tabular}{|c|c|c|c|c|c|}
\hline \multirow{2}{*}{$\begin{array}{l}\text { Struktura } \\
\text { dramatu }\end{array}$} & \multirow{2}{*}{$\begin{array}{c}\text { Ekspozycja } \\
\text { Scena } 1\end{array}$} & \multicolumn{2}{|c|}{ Rozwinięcie } & Kulminacja & Rozwiązanie \\
\hline & & Scena 2 & Scena 3 & \multicolumn{2}{|c|}{ Scena 4} \\
\hline $\begin{array}{l}\text { Wątki } \\
\text { główne }\end{array}$ & $\begin{array}{c}\text { Rozmowa } \\
\text { o pogodzie. } \\
\text { Zapewnienie } \\
\text { o podarowaniu } \\
\text { rocznicowego } \\
\text { prezentu }\end{array}$ & $\begin{array}{l}\text { Obietnica } \\
\text { wolności }\end{array}$ & $\begin{array}{l}\text { Niedosłowne } \\
\text { pożegnanie } \\
\text { małżonków }\end{array}$ & $\begin{array}{l}\text { Wręczenie } \\
\text { biletu. Pod- } \\
\text { sumowanie } \\
\text { małżeństwa. } \\
\text { Ostatecznie } \\
\text { rozstanie }\end{array}$ & $\begin{array}{l}\text { Ostatecznie } \\
\text { rozstanie }\end{array}$ \\
\hline Postaci & \multicolumn{5}{|c|}{ Ona, On } \\
\hline $\begin{array}{c}\text { Wątki } \\
\text { poboczne }\end{array}$ & & $\begin{array}{c}\text { Scena } 2 \\
\text { (początek) } \\
\text { I wątek pobo- } \\
\text { czny kontra- } \\
\text { punkt: } \\
\text { zapiski osoby } \\
\text { z zespołem } \\
\text { Aspergera. }\end{array}$ & $\begin{array}{c}\text { Scena } 3 \\
\text { II wątek pob- } \\
\text { oczny zatrzy- } \\
\text { manie akcji: } \\
\text { refleksje pary } \\
\text { bohaterów. }\end{array}$ & & $\begin{array}{c}\text { Scena } 4 \\
\text { (zakończenie) } \\
\text { III wątek } \\
\text { poboczny - } \\
\text { kontrapunkt } \\
\text { tablica } \\
\text { odlotów. }\end{array}$ \\
\hline Postaci & & Chór & Ona, On & & Chór \\
\hline
\end{tabular}

Tabela 1. Struktura dramatu uwzględniająca obecność wątków pobocznych.

34 A. Nowok, dz. cyt. 
[...] ma zupełnie nowy kontekst, związany, z jednej strony, z problemem egzystowania osób obarczonych chorobami ze spektrum autyzmu, z drugiej zaś z metaforycznym ujęciem braku porozumienia między dwojgiem ludzi ${ }^{35}$.

Reżyserka Maja Kleczewska nadała autyzmowi rolę swoistego motywu przewodniego zarówno Sudden Rain, jak i - wystawianej tego samego wieczoru - opery Between Agaty Zubel, czyniąc z choroby klucz do interpretacji obu przedstawień, „[...] metaforę współczesnych relacji międzyludzkich: wyalienowania, braku kontaktu czy chęci dogadania się" ${ }^{36}$. Zapiski osoby autystycznej pojawiają się na początku drugiej sceny Sudden Rain:

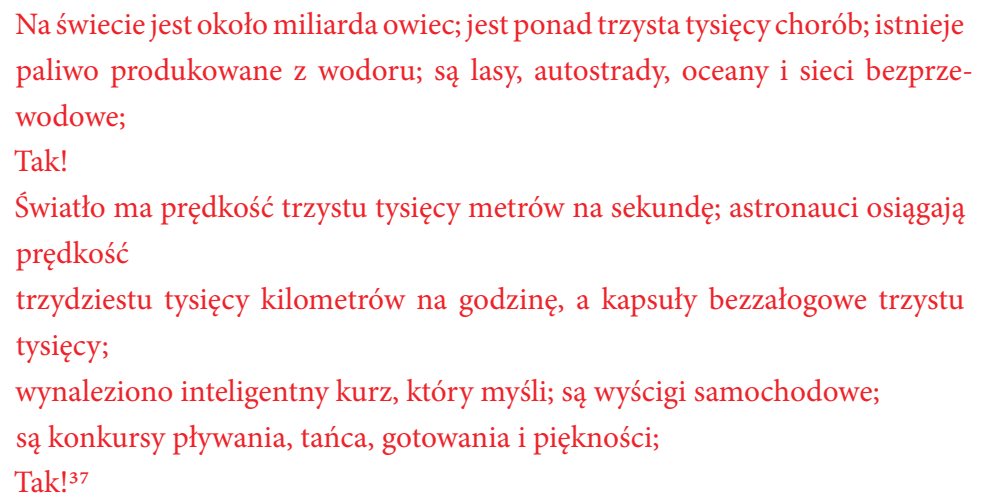

Wspomniane zapiski stanowią zbiór faktów oraz ciekawostek recytowanych przez chór i zupełnie niezwiązanych z głównym tematem opery. Dominują w nich wyliczenia oraz różne dane liczbowe. Kolejny tekst poboczny stanowi wypowiedź chóru zamykająca ostatnią, czwartą scenę, a tym samym całą operę. To odczytywana na głos tablica przyjazdów i odjazdów na lotnisku. W przeciwieństwie do wątków autystycznych w pewnym stopniu jest to nawiązanie do głównego tematu libretta, gdyż właśnie bilet stał się przysłowiową kością niezgody między głównymi bohaterami.

35 M. Stochniol, dz. cyt., s. 140.

36 M. Fuzowski, Sudden Rain, Beetwen, http://www.newsweek.pl/recenzje/sudden-rain-between,59314,1,1.html [dostęp: 13.04.2018].

A. Nowak, A Konieczna, Sudden Rain - libretto. 
W libretcie Sudden Rain można wyróżnić jeszcze jeden fragment poboczny, w którym zatrzymaniu ulega akcja. Jest nim scena trzecia najkrótsza i chyba najbardziej pesymistyczna. Otwierające ją słowa są wyraźnym odniesieniem do przyszłości:

ONA:

Cały świat zapada w sen,

Wszystkie słowa milkną.

ON:

Cały świat rozpada się,

Wszystkie słowa milkną.

RAZEM:

Zamilkły, upadły, przegrały, wyblakły, zanikły, upadły. ${ }^{38}$

Szczególnie sugestywnie brzmi fraza „cały świat rozpada się”, odnosząca się do problemu zaistniałego między małżonkami, który owocuje zakończeniem relacji i zerwaniem łączących ich więzi. Być może cała scena stanowi symboliczne pożegnanie bohaterów (prawdziwe pożegnanie nastąpi dopiero pod koniec sceny czwartej).

Mimo tragedii obojga bohaterów nie sposób nie odnieść wrażenia, że Ona i On wciąż się kochają, na co wskazuje wypowiedź kończąca scenę pierwszą:

ON:

W labiryncie odcisków twoich palców

błądzę szukając tajemnicy

tego, co czyni ciebie - tobą.

Zaglądam ci w oczy, kiedy śpisz,

wędruję poprzez twoje sny,

by ją odnaleźć.

Słucham, gdy do mnie mówisz,

wkładam twoje słowa do szuflad pamięci,

trzymam je tam na chwile takie, jak ta.

38 Tamże. 
ONA:

Drogi na opuszkach moich palców rozsupłują się dla ciebie,

z bram moich snów opadają kłódki, gdy podchodzisz,

jestem dla ciebie otwarta,

zapraszam cię do środka,

zobacz mnie, czytaj mnie, wychodzę ci na spotkanie. ${ }^{39}$

Co więcej, w końcowej scenie Ona wyraźnie podkreśla, że to On miał być jej towarzyszem do końca życia:

\section{ONA:}

Wybrałam ciebie,

kiedy cię poznałam.

Spojrzałam na ciebie i cię wybrałam.

W dniu naszego ślubu

spojrzałam ponownie, wybrałam ponownie

ciebie. $^{40}$

Libretto Sudden Rain przemawia wyjątkowo silnie głównie ze względu na codzienność przedstawionej sytuacji, przez co doskonale łączy się z ideą „życiopisania”. To platforma komunikacyjna między twórcami opery i jej odbiorcami, a przecież możliwość nawiązania więzi emocjonalnej oraz intelektualnej ze słuchaczem jest swego rodzaju credo Nowaka.

Melodia Sudden Rain balansuje na granicy dwóch różnych światów. Z jednej strony da się w niej słyszeć echa muzyki początków XX wieku (zdaniem Doroty Kozińskiej-Nowak „pokazał oblicze neosonorystyczne" ${ }^{41}$ ), z drugiej zaś charakteryzuje ją nowość i świeżość brzmieniowa. W rozwiązaniach harmonicznych zawarto dalekie odniesienia do systemu dur-moll, które często są bardziej widoczne w zapisie partyturowym. Wyraźnie wyczuwa się przy tym, że muzyka jest towarzyszką słowa, stanowiącego wartość nadrzędną. Podkreśla jego treść, symbolikę i przesłanie. Wypowiedzi głównych postaci to głównie melorecytacja, w której linia melodyczna odzwierciedla naturalną into-

39 A. Nowak, A Konieczna, Sudden Rain - libretto.

40 Tamże.

41 D. Kozińska, Dziwny przypadek dwojga noca, http://www.dziennikteatralny.pl/ artykuly/dziwny-przypadek-dwojga-nocna-pora.html [dostęp: 01.08.2018]. 


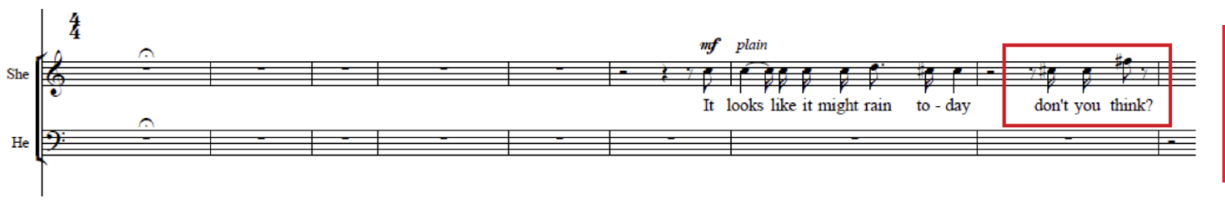

Przykład 1. Sudden Rain, scena pierwsza, wypowiedź Jej, figura retoryczna interrogatio, t. 30-37.

nację głosu, co wynika z ich konstruowania w odniesieniu do „sytuacji z życia" w libretcie opery. Brak zatem typowo wirtuozowskich partii solowych. Bardzo ważnym aspektem są liczne oznaczenia i komentarze dookreślające quasi-swobodną rytmikę, emocje czy dynamikę. Pojawiają się także rozwiązania nawiązujące do tradycyjnej retoryki muzycznej - figur, wśród których dominują interrogatio, emphasis, anabasis i katabasis (Przykład 1).

\section{Space Opera}

Ukończona w 2014 roku Space Opera powstała na zamówienie Teatru Wielkiego im. Stanisława Moniuszki w Poznaniu w ramach programu zamówień kompozytorskich Instytutu Muzyki i Tańca. Tam również została wystawiona po raz pierwszy w 2015 roku. Libretto napisał Georgi Gospodinov, bułgarski pisarz średniego pokolenia, zwany czasem „ironistą rozpaczy”. Głównym tematem opery jest pierwszy załogowy lot na Marsa, transmitowany przez stację telewizyjną $\mathrm{w}$ formacie reality show, którego uczestnikami są wybrani spośród grona kandydatów Adam i Ewa. Jednak okazuje się, że w sterylnie przygotowanej kapsule statku kosmicznego nie są sami. Oprócz obiektywu kamery towarzyszy im ktoś jeszcze, o czym kompozytor wspomina $\mathrm{w}$ komentarzu do utworu:

\footnotetext{
Pierwszoplanowym tematem libretta jest pierwsza załogowa wyprawa do planety Mars i z powrotem na Ziemię. Postaci występujące w tej historii to dwójka astronautów: małżeńska para w średnim wieku, pasażer na gapę: pozornie zwyczajna mucha, kierownik lotu będący również gospodarzem telewizyjnego reality show, oraz chór komentujący wydarzenia z dwóch perspektyw:
} 
zbiorowości ludzkiej pozostałej na Ziemi, oraz dusz zwierząt wysłanych przez człowieka w kosmos na różnych etapach eksploracji przestrzeni pozaziemskiej. Epizodycznie pojawiają się też Łajka, pierwszy w historii pies wysłany na orbitę, oraz Beduin prowadzący karawanę zwierzęcych dusz przez marsjańską pustynię. Małżonkowie na długie miesiące uwięzieni w maleńkiej kapsule muszą ułożyć sobie życie w nowych, kosmicznych realiach. Do głosu dochodzą rychło zwykłe, ziemskie sprawy. Ale obecne są też i te nieziemskie $[\ldots]^{42}$.

Jak można dostrzec, bodźców do skomponowania Space Opery dostarczyły autentyczne działania organizacji Mars One - prywatnego projektu holenderskiego przedsiębiorcy Basa Lansdorpa. Jej głównym założeniem jest wysłanie na Marsa grupy ludzi, których zadaniem będzie przeżycie na nieznanej dotąd ziemi. Spośród kilkuset zgłoszeń wyłoniono blisko stu kandydatów do pierwszej w historii załogowej misji na Czerwoną Planetę. Aby możliwe było jej sfinansowanie, organizacja planuje stworzyć reality show, sprzedając do niego prawa telewizjom na całym świecie ${ }^{43}$.

Mars One to globalna inicjatywa, której celem jest stworzenie misji dla każdego, także i ciebie. Jeśli będziemy działać razem, możemy to zrobić. Jedziemy na Marsa. Dołącz do nas! ${ }^{44}$

W rozmowie z Michałem J. Stankiewiczem kompozytor wspomina jednak o innym, acz bardzo podobnym projekcie, będącym swoistą inspiracją dla Space Oper $y^{45}$. Jest to misja ogłoszona przez fundację amerykańskiego milionera Dennisa Tito Inspiration Mars, która w dalszej perspektywie również przewiduje kolonizację Marsa. Wedle informacji umieszczonych na oficjalnej stronie przedsięwzięcia organizatorzy planowali w styczniu 2018 roku wysłać parę astronautów w podróż w dwie strony, by sprawdzić wytrzymałość człowieka podczas takiej próby ${ }^{46}$.

42 A. Nowak, Space Opera, http://www.aleknowak.com/pl/muzyka/sceniczne/ [dostęp: 23.02.2018].

43 Mars One, Mission, http://www.mars-one.com/mission [dostęp: 28.02.2017].

44 "Mars One is a global initiative whose goal is to make this everyone's mission to Mars, including yours. If we all work together, we can do this. We're going to Mars. Come along!" (Mars One - Mission, http://www.mars-one.com/mission [dostęp: 28.02.2017], tłumaczenie własne).

45 M. J. Stankiewicz, Odkrywać nierozpoznane, https://opera.poznan.pl/media/ uploaded/SPACE\%20OPERA/spaceopera_web.pdf [dostęp: 30.04.2018].

46 Tamże. 
Na fabułę Space Opery składają się przygotowania oraz podróż małżeństwa astronautów na orbitę Marsa. To z pozoru prosta historia, inspirowana prawdziwymi wydarzeniami - pierwszy wyznacznik „,̇̇yciopisania" w operze - a jednak nic nie jest w niej jednoznaczne, dzięki czemu otwiera się pole do wielu rozważań i spekulacji (nie wiadomo bowiem, czy kosmonautom uda się powrócić i jakie będą ich dalsze losy). Libretto Gospodinova zawiera w sobie z jednej strony elementy realistycznego świata, $\mathrm{z}$ drugiej zaś fantastyki i baśniowości. Zdaniem Marii Majewskiej: „Libretto posiada pewne cechy realizmu magicznego spod znaku Marqueza czy też Vargasa Llosy"47. Pojawienie się zwierząt obdarzonych uczuciami i pamięcią potęguje to wrażenie. Są one nie tyle postaciami epizodycznymi, co pełnoprawnymi bohaterami, mającymi kluczowy wpływ na rozwój akcji. Muszki Owocówki (bo o nich mowa) to: „[...] baczni obserwatorzy poczynań człowieka, często komentują wydarzenia widziane przez pryzmat własnych, jakże złożonych oczu"48.

W libretcie można wyróżnić trzy niezależne, ale wzajemnie się uzupełniające plany. Jest więc historia Adama i Ewy - pierwszej w historii pary kosmonautów, mających spędzić pięćset dni w kosmosie, w podróży na Marsa i z powrotem. Reprezentują ludzi przeżywających kryzys w związku, którzy chcąc spełniać się oraz realizować marzenia, często są zmuszeni iść na kompromis, jak pragnąca dziecka i zwyczajnego rodzinnego życia Ewa, decydująca się na podróż będącą niespełnionym marzeniem jej męża. Drugi plan to reality show - swoisty teatr w teatrze. Rolę mistrza ceremonii gra w nim Producent, dla którego wartość prymarną stanowi ilość widzów zebranych przed telewizorami (w partyturze pojawiają się partie chóru widzów, żywo reagujących na transmisję z kosmicznej podróży Adama i Ewy). Trzeci plan stanowi historia zwierząt, które poniosły śmierć w imię realizacji ludzkich mrzonek o wszechświecie (chór Muszek Owocówek w prologu do pierwszego aktu opery, arioso Łajki w prologu do drugiego aktu, chór wszystkich żywych stworzeń wysłanych kiedykolwiek w kosmos, a więc zarówno muszek, jak i psów, małp, a także ludzi, których prowadzi marsjański Beduin w epilogu).

Z pozoru prosta historia ujęta w libretcie jest w rzeczywistości skomplikowanym amalgamatem. Już sam tytuł - Space Opera - może sugerować odwołania do podgatunku fantastyki naukowej, skupiającego

47 M. Majewska, Małe historie pomiędzy science a fiction, https://opera.poznan.pl/ media/uploaded/SPACE\%2oOPERA/spaceopera_web.pdf [dostęp: 30.04.2018]. 48 Tamże. 
się wokół romantycznych przygód w kosmicznej przestrzeni, a także międzygwiezdnych podróży czy kosmicznych bitew, do czego zresztą kompozytor sam się przyznał w jednej z rozmów przeprowadzonych $\mathrm{z}$ okazji poznańskiego prawykonania:

\section{[...] tytuł Opera nawiązuje wprost do jednego z gatunków „science fiction”, popularnego w latach 7o. i 8o., ukazującego zazwyczaj perypetie miłosne bo- haterów w otoczeniu wszystkich fantastycznonaukowych atrybutów - lase- rów, kapsuł, obcych planet, kosmitów ${ }^{49}$.}

Akcja libretta Gospodinova przypomina przy tym ekranizację powieści Arthura C. Clarke’a 2001: Odyseja kosmiczna w reżyserii Stanleya Kubricka. Podobnie jak w Space Operze Nowaka fabułę stanowi tutaj wyprawa do krainy jutra. Przez wiele lat Kubrick był niedoścignionym wzorem i stał się inspiracją dla wielu twórców. W związku z tym można wyróżnić kilka filmów nawiązujących swoistą polemikę z Odyseją, jak choćby Marsjanin Ridley’a Scotta, którego akcja rozgrywa się w 2035 roku i opowiada losy astronauty Marka Watneya czy Interstellar Christophera Nolana, oparty na naukowej teorii tunelu czasoprzestrzennego amerykańskiego fizyka Kipa Thorne’a.

Pozostając w sferze telewizyjnego ekranu, warto poruszyć problematykę reality show stanowiącego jeden z trzech planów libretta Space Opery. Można doszukać się tu analogii do popularnego swego czasu programu Big Brother (a jednocześnie koncepcji reality show organizacji Dennisa Tito), który zaraz po swojej premierze w Polsce stał się przedmiotem narodowej debaty oraz uczonej dysputy, co zaowocowało powstaniem zbioru tekstów ujętych w tomie Podglądanie Wielkiego Brata pod redakcją Wiesława Godzica - filmoznawcy, medioznawcy i socjologa.

Podglądanie - punkt wyjścia dla programów typu reality show - to istotne pragnienie człowieka, które jednocześnie jest w stanie zagrażać jego rozwojowi ${ }^{50}$. Nie jest ono nowym zjawiskiem społecznym; swoistą popularność zyskało dopiero w drugiej połowie XX wieku, głównie zaś w Stanach Zjednoczonych, gdzie jako pierwsze powstawały programy typu reality show, w których istotną kwestią, na którą wskazuje Godzic, jest: „[...] brak wiedzy przedmiotu spojrzenia o tym, że

49 M. J. Stankiewicz, dz. cyt.

50 W. Godzic, „Wielki Brat” a sprawa polska, [w:] Podgladanie Wielkiego Brata, red. W. Godzic, Kraków 2001, s. 15. 
jest oglądany" ${ }^{1}$. Reality show lub szerzej - reality TV (tłumaczona jako „telewizja rzeczywistości”) obejmuje programy przedstawiające "prawdziwe życie” biorących w nich udział ludzi-aktorów widowiska sprzedawanego $\mathrm{w}$ czasie transmisji. W imię medialnej sławy i materialnych zysków gotowi są wyłączyć się z realnego społeczeństwa. Kulturoznawca, historyk kultury i antropolog kulturowy Roch Sulima wskazuje: „W społeczeństwie konsumpcyjnym życie społeczne steatralizowało się, stało się widowiskiem, na które patrzymy, ale rzadko realnie się w nie możemy włączyć" 52 .

Wydaje się, że literackim pierwowzorem dla tego typu programów był Rok 1984 George’a Orwella - opublikowana w 1949 roku antyutopia pełna politycznych podtekstów. Powieść opisuje Londyn w widzianej oczyma Orwella niezbyt odległej przyszłości, w której ludzkie życie w sposób całkowity zostaje podporządkowane władzy państwa. Kosmiczna podróż Adama i Ewy nasuwa jednocześnie skojarzenia z sesją na przysłowiowej kozetce u psychoanalityka. To swoista wiwisekcja relacji małżeńskiej. Na pierwszy plan wychodzą interesy i pragnienia obojga, jak się okazuje zupełnie odmienne (Ewa chce dziecka, Adam spełnienia dziecięcych marzeń o podróży na Marsa).

Maria Majewska trafnie opisała muzykę opery, porównując ją do emocjonalnego przewodnika po meandrach libretta ${ }^{53}$. Podobnie jak w omawianym wcześniej Sudden Rain towarzyszy słowu, przez co możliwe jest odczytanie tak ironii wypowiedzi, jak i szczerości oraz wzruszenia. W rozwiązaniach harmonicznych można dostrzec nawiązania zarówno do stanów emocjonalnych bohaterów, jak i grawitacji w danej scenie: im wyżej ku kosmicznej przestrzeni, tym mniejsze ciążenia harmoniczne, a im bliżej Ziemi, tym bliższe wydają się odniesienia do systemu dur-moll oraz funkcyjności.

Niezwykle ciekawe jest wprowadzenie podwójnej obsady wykonującej partię Muchy (kontratenor i sopran), co podkreśla jej dwoistą naturę, a także swoistą wyższość względem pozostałych postaci (Przykład 2.). To z kolei odsyła do twórczości literackiej autora libretta Georgiego Gospodinova, w której szczególnie ważne miejsce zajmują małe, często ignorowane stworzenia, a powracającą bohaterką jest musica domestica.

51 Tamże.

52 R. Sulima, Oko „Wielkiego Brata”, [w:] Poglądanie Wielkiego Brata, red. W. Godzic, Kraków 2001, s. 26.

53 M. Majewska, dz. cyt. 


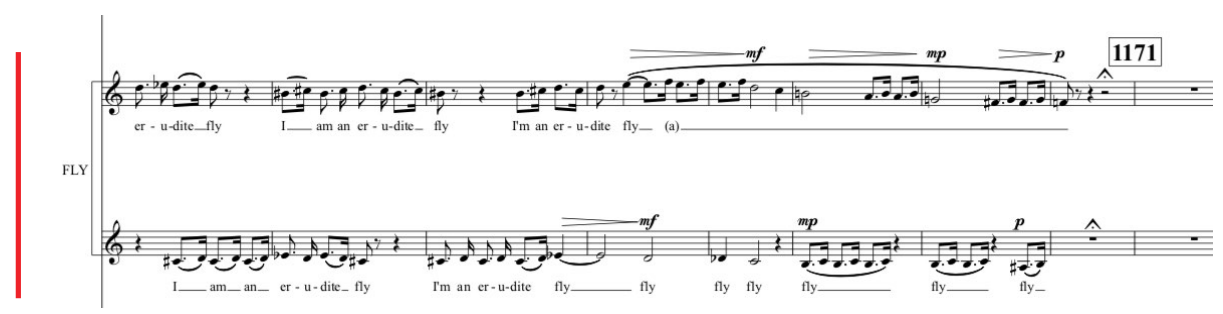

Przykład 2. Space Opera, scena szósta - partia Muchy, t. 1163-1171.

\section{Podsumowanie}

Konkluzja ma na celu nakreślenie głównych cech tytułowego „życiopisania" w twórczości operowej Aleksandra Nowaka przy jednoczesnej próbie charakterystyki jego stylu operowego. Zarówno w Sudden Rain, jak i w Space Operze pod płaszczykiem akcji kryje się historia zwykłych ludzi z bagażem doświadczeń. Inspiracji kompozytor szuka w życiu codziennym, wskazując niejako kondycję współczesnego człowieka, często zagubionego w świecie pełnym sprzecznych wartości i autorytetów.

Muzyka nie jest skoncentrowana na jednej technice czy stylu. $\mathrm{W}$ dużym stopniu wynika to $\mathrm{z}$ chęci podążania za konkretnymi stanami i "kręgiem emocji", które Nowak docelowo chciałby wywołać u odbiorców. Wykorzystuje zatem środki oraz techniki, a także formy i gatunki znane mu $\mathrm{z}$ historii muzyki: liczne cytaty (na przykład melodia modlitwy Ojcze Nasz bądź motyw z uwertury do poematu symfonicznego Ryszarda Straussa Also sprach Zarathustra w Space Operze), groteskę i muzykę popularną (przy charakterystyce postaci Producenta i telewizyjnego świata, który reprezentuje), techniki kompozytorskie tak z dalekiej przeszłości (imitacja, fuga), jak i z XX oraz XXI wieku (aleatoryzm, serializm), a także świadome nawiązania do opery czy oratorium.

Jadwiga Paja-Stach wyróżnia dwie postawy artystyczne wobec tradycji muzycznej, różnie traktujące „spuściznę przeszłości”. Pierwszą określa mianem buffo, przez co rozumie ludyczność i dystansowanie się do tradycji historii muzyki, co często jest wyrażane poprzez parodię dawnych stylów, groteskę lub łączenie starego $\mathrm{z}$ nowym w formie swego 
rodzaju gry, sprawdzającej znajomość różnych konwencji u słuchacza ${ }^{54}$. Druga, określona jako postawa seria, polega na:

[...] potraktowaniu technik z dawnych epok i technik dwudziestowiecznych na zasadzie fuzji stylistycznej; i nawet w przypadku cytatu z muzyki tradycyjnej funkcjonuje on raczej na zasadzie symbolu, a nie - elementu ludycznego ${ }^{55}$.

W twórczości operowej Aleksandra Nowaka wyczuwalne jest głębokie zakorzenienie w tradycji, będące niejako wyrazem idei postmodernistycznej w postawie seria.

\section{Bibliografia}

Buchnowski M., Buty Ikara. Biografia Edwarda Stachury, Warszawa 2014, http://www.polskatimes.pl/kultura/ksiazki/a/stachurastworzyl-zyciopisanie-jego-pisarstwo-bylo-tozsame-z-jego-zyciem,12510960/ [dostęp: 31.03.2018].

Chłopecki A., MUZYKA 2.1: Aleksander Nowak, http://www.dwutygodnik.com/artykul/1116-muzyka-21-aleksander-nowak.html [dostęp: 12.12.2016].

Fuzowski M., Sudden Rain, Beetwen, http://www.newsweek.pl/recenzje/sudden-rain--between,59314,1,1.html [dostęp: 13.04.2018].

Godzic W., „Wielki Brat” a sprawa polska, [w:] Pogladanie Wielkiego Brata, red. W. Godzic, Kraków 2001.

Gwarancje Kultury - Telewizja Polska, http://www.tvp.pl/kultura/wydarzenia/gwarancje-kultury/laureaci-2011 [dostęp: 11.12.2017].

Kozińska D., Dziwny przypadek dwojga noca, http://www.dziennikteatralny.pl/artykuly/dziwny-przypadek-dwojga-nocna-pora.html [dostęp: 01.08.2018].

Majewska M., Małe historie pomiędzy science a fiction, https://opera. poznan.pl/media/uploaded/SPACE\%20OPERA/spaceopera_web. pdf [dostęp: 30.04.2018].

54 J. Paja-Stach, Kompozytorzy polscy wobec idei modernistycznych i postmodernistycznych, s. 57, [w:] Modernizm i postmodernizm w poetyce kompozytorskiej i w refleksji o muzyce, red. A. Jarzębska, J. Paja-Stach, Kraków 2007, s. 55-74.

55 Tamże 
MarsOne, Mission, http://www.mars-one.com/mission [dostęp: 28.02.2017].

Nowok A., Aleksander Nowak, http://musicfrompoland.eu/artykul/ aleksander-nowak-7 [dostęp: 08.08.2017].

Nowok A., Wizytówka Aleksandra Nowaka, http://meakultura.pl/publikacje/wizytowka-aleksandra-nowaka-771 [dostęp: 12.12.2016].

Paja-Stach J., Kompozytorzy polscy wobec idei modernistycznych i postmodernistycznych, [w:] Modernizm i postmodernizm w poetyce kompozytorskiej i $w$ refleksji o muzyce, red. A. Jarzębska, J. Paja-Stach, Kraków 2007.

Rydzek D., Reality show - geneza i rodzaje, https://naekranie.pl/artykuly/reality-show-geneza-i-rodzaje [dostęp: 30.04.2018].

Stankiewicz M.J., Odkrywać nierozpoznane, https://opera.poznan.pl/ media/uploaded/SPACE\%2oOPERA/spaceopera_web.pdf [dostęp: 30.04.2018].

Stochniol M., "Sudden Rain" (2008) Aleksandra Nowaka. Niezwyczajna opera o zwyczajnych problemach, „Res Facta Nova” 2013, nr 14 (23).

Strona internetowa kompozytora, http://www.aleknowak.com.pl/ [dostęp: 10.12.2016].

Sulima R., Oko „Wielkiego Brata”, [w:] Podgladanie Wielkiego Brata, red. W. Godzic, Kraków 2001.

Terytoria, http://teatrwielki.pl/activity/artistic-projects/territories/ [dostęp: 07.08.2017].

Topolski J., Nowe otwarcie: jesteśmy kosmitami, rozmowa z Aleksandrem Nowakiem, http://www.dwutygodnik.com/artykul/5917-nowe-otwarcie-jestesmy-kosmitami.html [dostęp: 23.02.2018].

Trzęsiok M., Muzyka rzeczywistego świata. Rozmowa $z$ Aleksandrem Nowakiem, „Kwarta. Magazyn o polskiej muzyce współczesnej"2011, nr 1 (16), https://pwm.com.pl/pliki/2/6/4/2637_2158_ Kwartanr1sierpien2011.pdf [dostęp: 10.12.2016].

University of Louisville, Bomhard Fellowships in Music Composition, http://louisville.edu/music/academics/areas-of-study/music-composition/moritz-von-bomhard-fellowships-in-music-composition [dostęp: 26.04.2017].

http://festiwalprawykonan.pl/kompozytorzy-nowak-aleksander.php [dostęp: 15.06.2018].

http://ninateka.pl/audio/aleksander-nowak-fiddlers-green-and-white-savannas-never-more-aksamitna-kurtyna-2 [dostęp: 19.03.2018]. 